\section{Will monitoring suffice when the hunting stops?}

Tokyo

JAPAN's Fisheries Agency has endorsed a new plan designed to keep Japan in the whaling business after the moratorium on whaling agreed by the International Whaling Commission (IWC) comes into effect at the end of 1985 .

The plan, put forward by the "Study Council on the Whaling Problem", an advisory body to the chief of the Fisheries Agency, actually calls for Japan to end commercial whaling in accordance with the IWC ban. But it simultaneously calls for Japan to begin "investigative whaling" the hunting of whales to "check scientifically on whale resources"'. And despite a statement from the Fisheries Agency chief that investigative whaling would "not be in search of profit but aimed at the assessment of resources", any real difference from present commercial operations has yet to be made clear. The same whaling fleet of one mother ship and four catchers would be used, and whales caught for "survey" would still be processed and sold for food. At the same time, Japan is to press the view that whaling operations within its own 200-mile zone should be allowed on the same grounds that the "aboriginal subsistence whaling" of the Eskimos of Alaska is allowed - that they are vital to the "social, economic and cultural life" of local communities.

Behind all this semantic juggling lies the great sense of anger felt by the Japanese over what they see as the "moral imperialism" and "tyranny" of IWC - coupled with the knowledge that any direct defiance of IWC will result in the automatic imposition of economic sanctions against Japan by the United States.

The latest meeting of IWC, held in Buenos Aires in June, agreed massive cuts in whaling quotas for 1985, the last year before commercial whaling is due to be phased out. The quota for southern minke whales, which has accounted for 90 per cent of Japan's catch, is to go down from this year's figure of 6,655 to 4,224 - a level which will make it virtually impossible for the industry to continue operating at a profit next year, given that the quota must be shared with the Soviet Union.

In theory, Japan can simply lodge a formal objection to the quota and be freed from any obligation to observe it since IWC has no enforcement powers. Indeed, that is exactly what Japan did, along with the Soviet Union and Norway, when IWC first agreed the commercial ban in 1982 . But the problem is that the PackwoodMagnuson amendment to the US Fisheries Act requires that any country defying IWC resolutions be penalized by cuts in their fishing quotas in the US 200-mile zone. And those fish are worth far more to Japan than are the whales $(120,000$ million yen a year against 8,500 million yen a year). Japan's 1982 objection led to the imposition of a 10 per cent cut in the quota by the United States, and if Japan actually goes ahead and simply defies IWC then the fishing quota might be cut to zero by the United States.

The Japanese take particular offence at this year's IWC decision because they do not believe it was made on the basis of scientific evidence nor from a desire to keep whale stocks safe from extinction, but on moral grounds under pressure from conservationists. They point out that some members of IWC (membership is open to any country) have never had any financial interest in whaling and that Japanese surveys show there to be more than 400,000 minke whales in the Antarctic Ocean.

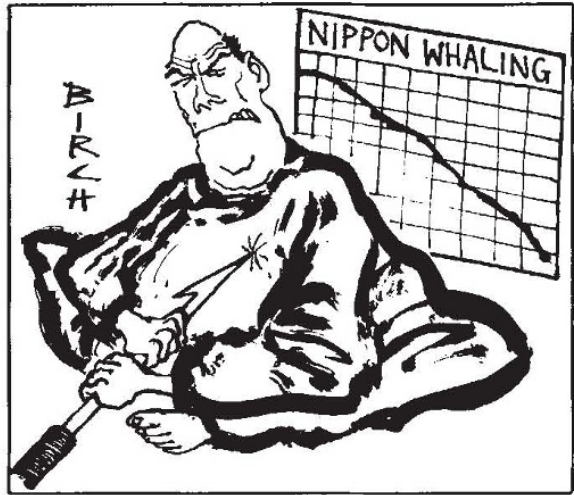

The Japanese, with their long Buddhist traditions, are not strangers to moral restrictions on the killing of animals. In the seventeenth century, one of Japan's more eccentric rulers, the fifth Tokuga Shogun, Tsunayshi, went so far as to ban the killing of virtually all living things and to require that dogs be spoken to in a polite manner "honourable canine" being the preferred form of address. But having moral precepts forced upon them by another country is not something the Japanese can take easily. The hunting of whales has a long tradition behind it, and Japanese feel much the same way about the ban as an Englishman might if the supply of roast beef were to end as a result of economic pressure from the Hindu countries.

The official IWC view, however, is that its resolutions express scientific caution, not moral viewpoints. Nobody knows for certain how many whales there are and modelling population behaviour and the effects of whaling is fraught with difficulties: it is better to err on the side of caution than to drive a species to extinction.

What will happen next depends largely on the United States, which has already indicated its willingness to hold a meeting of countries actually involved in whaling. If the United States prevails upon Japan to stop whaling, then it is likely that the Soviet Union will also obey the IWC moratorium for it relies upon Japan to buy virtually all the whale meat it takes. That will leave only Norway, which has a relatively small whaling operation. The Japanese are hoping that they can persuade the United States whose fishing bans they can counter with bans on the import of US fish products not to impose fishing sanctions and persuade IWC to agree to "investigative whaling" until the end of its moratorium in 1991. By then, Japanese whalers believe they will have enough evidence to persuade IWC that commercial whaling can be contained without risk to whale species.

Alun Anderson

\section{Whitehead Institute}

\section{moves in}

THE Whitehead Institute for Biomedical Research began to occupy its handsome new building at the edge of the MIT campus in Cambridge, Massachusetts, last week with all the informality of a commune moving house. Graduate students and senior faculty alike were lugging boxes of equipment across the street. At one stage Dr Robert A. Weinberg, wearing a yellow and blue striped rugby jersey, was to be seen on the tailboard of a moving van protecting his rubber plant, now fourteen years old.

The controversies of three years ago, when the institute was founded with a benefaction of $\$ 135$ million by Mr Jack Whitehead, the founder of Technicon, sold to the Revlon cosmetics corporation in 1980, seem largely to have been stilled. Alarm that the Whitehead Institute might skew the pattern of biological research at MIT has been dissipated with the appointment of the first members of the institute, whose interests are as catholic as most people would wish. The agreement with MIT requires that faculty appointments should be jointly made, following strict MIT procedures, with seven years of probation for all but established people.

David Baltimore, the Whitehead director, says that he hopes to concentrate the institute's work in developmental biology, and that the number of faculty members should eventually double to 16 . (Not unnaturally, he is now on the look-out for a drosophilogist with more than a nodding acquaintance with homoeotic genes.) Baltimore, still a little surprised that doors are repainted when he asks for that to be done, promises that he will spend as little time as possible in his large front office. One bone of contention with the biology department is that the Whitehead Institute is superbly equipped and enviably staffed with administrators. 